РЕГУЛЮВАННЯ ЗЕМЕЛЬНИХ ПРАВОВІДНОСИН НА ВОЛИНІ У 1939 - 1941 рр. ЯК ЗАСІБ ЕКОНОМІЧНОГО ПОСЛАБЛЕННЯ СЕЛЯНСЫКИХ ГОСПОДАРСТВ

\author{
Михайло Махаринець \\ аспірант кафедри історії держави та права \\ Національної академії внутрішніх справ (Київ, Україна) \\ ORCID ID: 0000-0003-1478-1306
}

\begin{abstract}
Анотація. У положеннях наукової статті автор аналізує вплив і наслідки правової регламентації земельних відносин, яку здійснювала радянська влада стосовно індивідуальних селянських господарств на Волині у 1939-1941 роках.

Використано таку систему методів наукового пізнання: формальну логіку, а також емпіричний, порівняльний і джерелознавчий методи з метою детального з'ясування змісту досліджуваних питань, метод системного аналізу - для узагальнення особливостей правового регулювання земельних відносин. Аналіз статистичних даних здійснювався на основі методів зіставлення паралельних даних та аналітичних групувань.

Мета статті - на основі аналізу організаційно-правових засад діяльності радянської держави як учасника земельних відносин спростувати пануючу в науковій літературі тезу про передачу переважної більшості конфіскованої у 1939-1941 роках поміщицької та церковної землі малоземельним і безземельним селянам 3 метою покращення їх матеріального добробуту та встановлення соціальної справедливості.

У результаті аграрних трансформацій у 1939-1941 роках на Волині малоземельним і безземельним селянам було передано не досить конфіскованої землі для ведення самоокупного господарства, а середняцькі господарства через відчуження землі, яка виходила поза встановлені радянською владою граничні норми індивідуального землекористування, було перетворено в економічно слабкі. Заходи радянської влади у сфері правового регулювання земельних відносин переслідували мету не встановити соціальну справедливість і покращити добробут сільського населення, а за допомогою суворої регламентації та посилення державного контролю земельних відносин перетворити більшість індивідуальних селянських господарств в економічно слабкі, які не зможуть вистояти перед зростаючим тягарем державних податків. Більшість конфіскованої землі перейшла не до селянських господарств, а до радянської держави через ії суб'єкти господарювання - новостворені колгоспи і радгоспи, а також державний земельний фонд.

Ключові слова: земельні відносини, конфіскація, обмеження землекористування, селянське господарство.
\end{abstract}

\title{
LEGAL REGULATION OF LAND RELATIONS IN VOLHYN IN 1939 - 1941 AS A MEANS OF ECONOMIC DEROGATION OF INDIVIDUAL PEASANTS' FARMSTEADS
}

\author{
Mykhailo Makharynets \\ Postgraduate Student at the Department of History of State and Law \\ National Academy of Internal Affairs (Kyiv, Ukraine) \\ ORCID ID: 0000-0003-1478-1306
}

\begin{abstract}
In the statements of the scientific article author analyses influence and consequences of the legal regulation of land relations which was conducted by soviet government in relation to individual peasants farmsteads in Volhyn in 1939-1941.

The system of methods of scientific cognition is used: formal logic, empirical, comparative and source study methods to find out in detail content of studied questions. Method of system analysis is used for generalization of peculiarities of legal regulation of land relations. Analysis of statistic data was conducted on the basis of comparison parallel data and analytic assortment methods.

Aim of article. Based on the analysis of the organizational and legal grounds of activity of soviet government as a participant of legal relations to refute a dominant thesis in scientific literature about the transfer of majority of confiscated in 1939-1941 years landlord and church lands to a landless or partially landless peasants for the purpose of developing their material welfare and establishment of social justice.

As a result of agricultural transformations in 1939-1941years in Volhyn there was not enough confiscated land transferred to landless or partially landless peasants for conducting self-sustaining farmstead. While the middle farmsteads because of the dispossession of the lands which was stepping out from the established by soviet government limiting measures of individual land use were turned to economically weak. Actions taken by soviet government in the sphere of legal regulation of land relations pursued a goal not to establish social justice and improve welfare of rural population, but to transfer majority of the peasants' farmsteads to economically weak which won't be able to stand tax bargain with the strict regimentation and intensified state control. Most of the confiscated land was transferred to soviet government through its commercial entities - collective and state farms, state land fund and not to peasants farmsteads.
\end{abstract}

Key words: land relations, confiscation, limitation of land use, peasant farmstead. 


\title{
REGULACJA STOSUNKÓW ROLNYCH NA WOLYNIU W LATACH 1939 - 1941 JAKO ŚRODEK OSŁABIENIA GOSPODARCZEGO GOSPODARSTW CHLOPSKICH
}

\author{
Mykhailo Makharynets \\ aspirant Wydziału Historii Państwa i Prawa \\ Narodowej Akademii Spraw Wewnętrznych (Kijów, Ukraina) \\ ORCID ID: 0000-0003-1478-1306
}

Adnotacja. W tezach artykułu naukowego autor analizuje wpływ i skutki regulacji prawnych stosunków rolnych, jakie sprawowała władza radziecka wobec indywidualnych gospodarstw chłopskich na Wołyniu w latach 1939-1941.

Zastosowano system metod poznania naukowego: logikę formalną, a także metody empiryczne, porównawcze i źródłowe-w celu szczegółowego wyjaśnienia treści badanych kwestii, metodę analizy systemowej-w celu podsumowania cech regulacji prawnych stosunków rolnych. Analiza danych statystycznych została przeprowadzona na podstawie metod porównywania danych równoległych i grup analitycznych.

Celem artykułu - na podstawie analizy organizacyjno-prawnych podstaw działalności państwa radzieckiego jako uczestnika stosunków obalić panującą w literaturze naukowej tezę o przeniesienie większości skonfiskowanej w latach 1939-1941 ziemi ziemiańskich i kościelnych małorolnym i bezrolnym chłopom w celu poprawy ich dobrobytu materialnego i ustanowienia sprawiedliwości społecznej.

W wyniku transformacji rolnych w latach 1939-1941 na Wołyniu chłopom małorolnym i bezrolnym przekazano niewystarczającą skonfiskowaną ziemię do prowadzenia samowystarczalnej gospodarki, a gospodarstwa średnie poprzez alienację ziemi, która wykraczała poza ustalone przez władze radzieckie limity indywidualnego użytkowania gruntów, przekształcono w ekonomicznie słabe. Działania władz radzieckich w zakresie regulacji prawnych stosunków rolnych miały na celu nie ustanowienie sprawiedliwości społecznej i poprawę dobrobytu ludności wiejskiej, ale poprzez ścisłe regulacje i wzmocnienie kontroli państwowej stosunków rolnych, przekształcenie większości indywidualnych gospodarstw chłopskich w ekonomicznie słabe, które nie będą w stanie wytrzymać rosnącego obciążenia podatkami państwowymi. Większość skonfiskowanej ziemi nie przeszła na gospodarstwa chłopskie, ale na państwo radzieckie poprzez jego podmioty gospodarcze - nowo utworzone kołchozy i sowchozy, a także Państwowy Fundusz Ziemi.

Słowa kluczowe: stosunki rolne, konfiskata, ograniczenie użytkowania gruntów, gospodarstwo rolne.

Вступ. Нині Україна стоїть перед проблемою обрання такої моделі правовідносин у сфері сільського господарства, яка б надала найбільші можливості розкрити економічний потенціал країни. Сучасні проблеми у сфері землеволодіння і землекористування потребують не лише ситуативного юридичного вирішення, але й розуміння глибинних процесів їхнього формування та еволюції в різних регіонах України у XX столітті.

Вплив і наслідки правової регламентації земельних питань, яку здійснювала радянська влада стосовно західноукраїнського села, проаналізовано у дослідженнях П. Когута, М. Кучерепи, Б. Яроша та О. Малярчука. Негативний вплив радянських аграрних перетворень на розвиток правової культури українського народу розглядають Л. Кучма та В. Старка. Основу джерельної бази статті складають архівні матеріали Державного архіву Рівненської області в місті Рівне.

Використано таку систему методів наукового пізнання: формальну логіку, а також емпіричний, порівняльний і джерелознавчий методи з метою детального з'ясування змісту досліджуваних питань; метод системного аналізу - для узагальнення особливостей правового регулювання земельних відносин. Аналіз статистичних даних здійснено, грунтуючись на методах зіставлення паралельних даних і аналітичного групування.

Мета статті - на основі аналізу організаційно-правових засад діяльності радянської держави як учасника земельних відносин спростувати панівну в науковій літературі тезу про передавання більшості конфіскованої в 1939-1941 роках поміщицької та церковної землі малоземельним і безземельним селянам для покращення їхнього добробуту та встановлення соціальної справедливості.

Основна частина. 3 приходом восени 1939 року радянської влади на Волинь відбулася кардинальна зміна у сфері земельних правовідносин: ліквідація приватної власності на землю та перехід іiі в державну власність, конфіскація великого землеволодіння. Радянський режим перетворив власників землі на землекористувачів, лімітувавши розміри земельних ділянок. Усе це робилося під ідеологічним гаслом ліквідації соціальної несправедливості. Дійсно, незважаючи на аграрну реформу, яка відбулася в міжвоєнній Польщі, проблему «земельного голоду» на селі вирішити не вдалося.

Приблизно половина селянських господарств на Західній Україні, зокрема й на Волині, були економічно збитковими і не могли себе прогодувати. Поряд зі значною кількістю малоземельних селянських господарств були наявні і величезні поміщицькі латифундії. Такий розподіл земельної власності неминуче спричиняв зростання незадоволення населення. До цього потрібно додати соціальну й політичну напругу на Волині, спричинену непродуманою соціально-економічною політикою польського уряду щодо української національної меншини, посиленої польським осадництвом (Романишин, 2020: 97).

У значної категорії місцевого населення були сподівання, що радянська влада подолає головну економічну проблему на селі - «земельний голод» шляхом експропріації великого землеволодіння та роздавання його малоземельним і безземельним селянам. Саме це й обіцяла радянська влада місцевому українському населенню, коли Червона армія перейшла державний кордон із Польщею й окупувала Західну Україну та Західну Білорусію.

Під гаслом конфіскації поміщицької землі радянська влада проводила агітаційну роботу в ході організації Народних Зборів Західної України. Цей представницький орган юридично мав задекларувати волю 
населення Західної України. 27 жовтня 1939 року Народні Збори Західної України ухвалили Декларацію про входження Західної України до складу СРСР і приєднання ії до складу УРСР, що забезпечило легітимну основу запровадження радянської системи управління.

3 приєднанням Західної України до складу УРСР земельні відносини на Галичині та Волині зазнали докорінних змін. Підставою для припинення права приватної власності на землю та зміни суб'єктного складу земельних правовідносин стало прийняття й набуття чинності Декларації Народних Зборів Західної України від 28 жовтня 1939 року про конфіскацію земель поміщицьких, монастирських і великих державних урядовців. «Уся земля Західної України з їі надрами, всі ліси та ріки оголошувалися всенародним добром, тобто державною власністю» (Возз'єднання українського народу, 1949: 49-50).

Запроваджувалося примусове позбавлення майнових прав певних категорій населення та вилучення їхнього майна на користь держави, а також припинення права приватної власності на землю усіх господарів, оскільки землю тепер визнавали державною власністю. Зі встановленням радянської влади націоналізація стала основним способом позбавлення всього населення права власності на землю. Потрібно зазначити, що радянська націоналізація була безоплатною - колишнім власникам жодним чином не компенсували вартість втраченої землі. Націоналізація призвела до цілковитої ліквідації великого землеволодіння поміщицьких і церковних земель, решту землевласників перетворили з приватних власників земельних ділянок на їх користувачів.

Більшовицька влада декларувала, що розподілення конфіскованих земель здійснюватимуть селянські комітети, сформовані з місцевого населення. Хоча насправді розподіл конфіскованих земель відбувався під керівництвом і наглядом державних та партійних структур, про що свідчать тогочасні протоколи засідань сільських рад. Наприкінці таких протоколів завжди зазначали, що документ подано на затвердження до районного комітету КП(б)У або до виконкому районної ради депутатів (ДАРО Ф Р-635, оп. 1, спр. 95, арк. $51,78,87)$. Це свідчить про несамостійність місцевих органів влади у вирішенні земельних питань та позірну демократичність і народовладдя, декларовані комуністами.

Радянська історіографія завжди наголошувала, що конфісковану землю передавали здебільшого селянам. Досліджуючи механізм передавання землі, дослідники зазначали, що селянські комітети «брали на облік i безкоштовно розподіляли між безземельними та малоземельними селянами десятки тисяч гектарів сільськогосподарських угідь, поміщицьке майно» (Історія Української РСР, 1977: 501). На жаль, на цей ідеологічний штамп можна натрапити як в українських дослідженнях 1990-х (Вісин, 1997: 19), так і в найновіших (Мартин, Прядка, 2019: 135; Стасюк, 2020: 108).

Архівні ж історичні джерела свідчать про протилежне - тільки незначна частка конфіскованих поміщицьких і церковних земель переходила в користування селян. Так, постановою засідання селянського комітету села Квасилова Рівненської області від 17 жовтня 1939 року конфісковані землі тільки частково були передані селянам. Однак і це було зроблено у такий спосіб, що в селі «земельний голод» не було втамовано. Безземельні селяни отримали невеликі ділянки, площа яких не перевищувала тієї, яка була в користуванні малоземельних селян (ДАРО Ф. Р-635, оп. 1, спр. 95, арк. 50).

Зрештою радянська влада не ліквідувала навіть таке явище як безземелля. У документах відділу землеустрою Рівненського обласного управління сільським господарством збереглася порівняльна таблиця структури господарств за розмірами земельних ділянок землекористувачів. Вона свідчить, що в 1939 року всього нараховувалося 209245 господарств, із яких було 12417 господарств безземельних селян, що становило 5,93\%, а в 1941 році за наявності 205043 всіх господарств безземельними залишалися 5 041, що становило 2,5\% від усіх господарств.

Кількість малоземельних господарств, які мали від 0 до 2 га землі, зменшилася з 52016 до 46135 господарств (на 2,36\%), малоземельних господарств, які володіли від 2 га до 5 га, - 388841 у 1939 році до 87227 (на 1,47\%), середняцьких - збільшилося на 4,57\% з 54260 до 62462 господарств. Причому більш як половина усіх селянських господарств, а саме 138403 (67,5\%), які мали від 1 га до 5 га землі, уже навіть після перерозподілу земель і одержання поміщицької землі все ж залишилися малоземельними (ДАРО Ф. Р-635, оп. 3, спр. 102, арк. 1). Усього в Рівненській області було націоналізовано 540561 га землі, але лише 105197 га з неї було передано в користування «колгоспам і селянам». Решту земельного фонду було віддано держлісфонду, радгоспам та іншим державним установам (ДАРО Ф. Р-635, оп. 1, спр. 115, арк. 4).

Зосередження в державному резерві цієї кількості землі свідчило про те, що радянська влада не була зацікавлена у розвитку індивідуального селянського виробництва, а навпаки готувалася до його ліквідації. Така політика в регулюванні земельних відносин свідчить, що більшовики не ставили собі за мету створити економічно міцні середняцькі селянські господарства. Головне завдання полягало у тому, щоб подолати приватновласницькі тенденції як ворожі самій суті радянської системи і стимулювати розвиток колективістських тенденцій - основи радянського тоталітарного режиму. Господарства до 5 га не були самоокупними, тому таких селян підштовхнути до вступу у колгосп було набагато легше як з економічного, так і з психологічного погляду.

Аналізуючи дані порівняльної таблиці земельного фонду Рівненської області станом на 17 вересня 1939 року і 1 січня 1941 року, бачимо, що більшість земельної площі перейшла не до селян, а до держави. Так, площа земель в одноосібників після роздавання та перерозподілення збільшилася усього на 74995 га 31111217 га до 1186212 га. Водночас державний земельний фонд нараховував 11936 га землі, державний лісовий фонд - 656163 га, державні установи й організації отримали 38044 га, радгоспи - 11864 га, колгоспи - 30202 га (ДАРО Ф. Р-635, оп. 3, од. зб. 28, арк. 3).

Разом 3 ліквідацією великого землеволодіння відбувалося обмеження землекористування через лімітацію радянською державою розмірів земельних ділянок. Із досліджених архівних документів випливає певна законо- 
мірність у діях радянської влади щодо розподілення конфіскованих земель: поміщицькі та церковні здебільшого ставали володінням колгоспів і радгоспів, а «надлишки» середняків передавалися частково новоствореним колгоспам і державному земельному фонду, а частково - малоземельним односельцям. Очевидно, що така тактика радянської влади була не випадковою - за рахунок конфіскації землі у середняків, яких почали називати «куркулями», і передавання їі біднякам, радянська влада сподівалася отримати не лише лояльність і підтримку незаможних селян, але й спровокувати соціальний конфлікт на селі.

Варто зауважити, що позиція селян чітко залежала від їхнього майнового стану. Започатковані більшовиками аграрні новації спричинили неоднозначну реакцію людей - від цілковитого заперечення до абсолютної підтримки. Незаможне населення прихильно поставилося до більшовиків, повіривши їхнім гаслам, сільська біднота не нехтувала можливістю привласнити «панське» майно. Середняки дотримувалися вичікувальної позиції, а заможне селянство та прихильники націоналістичних організацій - відверто ворожої (Старка, 2019: 99).

Постанова Центрального Комітету КП(б)У та Раднаркому УРСР від 24 березня 1941 року встановлювала граничні норми індивідуального землекористування. На Галичині - 7 га на один селянський двір, а на Волині - до 10 га. У північних лісових районах Волинської та Рівненської областей граничні норми землекористування на один двір становили 15 га. Площу землі, яку селяни мали понад норму, відрізали. Вилучення земель здійснювали сільські ради з подальшим затвердженням результатів земельного устрою районними виконавчими органами. Центральний Комітет КП(б)У і Раднарком УРСР для виконання цієї роботи відправляли на місця відповідних працівників. У такий спосіб «лишки» землі вилучили у 4\% селянських господарств. Площа таких «лишків» становила майже 205 тис. га землі (Коріненко, 2015: 301).

Хоча радянська історіографія постійно підкреслювала, що за постановою про відрізання надлишків землі у багатосімейних селянських дворів, які мали земельні ділянки за розміром більші, ніж передбачали граничні норми, але самотужки обробляли їх, землю не відрізали (Варецький, 1960: 217), архівні джерела свідчать про протилежне. У цьому контексті становлять інтерес протоколи та постанови селянських рад Рівненської області щодо перерозподілення земель між селянськими господарствами в 1941 році. Аналіз статистичних даних щодо селянських господарств (кількості орної, присадибної, сіножатної землі та лісів), кількості осіб у родині, здійснений за методами зіставлення паралельних даних та аналітичного групування, дає змогу дійти висновку, що зазначеного вище принципу на практиці не дотримувалися.

Це яскраво ілюструє протокол засідання II сесії виконкому Колоденської сільради депутатів трудящих, яка відбулася 30 березня 1941 року. У «надлишки» потрапляла здебільшого найцінніша земля - орна, тому конфісковували саме іiі. Як результат після «відрізання лишків» у селян землі залишалося менше, ніж було дозволено нормою. Наприклад, у селянина Болеслава Мусина (5 осіб у сім’ї), який володів 22,99 га землі, 3 яких присадибної - 1 га, орної - 18,96 га, вилучили 12,99 га орної. Кричущий випадок: у селянина Михайла Мазуркевича (7 осіб у сім'ї), який володів 11,58 га землі, з них присадибної - 0,44 га, орної - 8,84 га, сіножаті - 1 га, лісів 1,30 га, було конфісковано 1,58 га орної (ДАРО Ф. Р-635, оп. 1, спр. 95, арк. 57). Отже, у селянській родині з семи осіб орної землі залишилося лише 8 га.

В Острозькому районі Рівненської області на квітень 1941 року за даними щодо 49 сіл було відрізано 837,22 га землі, із них орної - 641,87 га, сіножаті - 104,41 га, лісів - 64,85 га, іншої - 26,09 га (ДАРО Ф. Р-635, оп. 1, спр. 104, арк. 2). Зіставлення протоколів засідань сесій у селах Рівненської області в 1941 році чітко засвідчує тенденцію, за якою після «відрізання» практично не залишилося селянських господарств із площею орної землі у 10 га, визначені радянською владою за норму (ДАРО Ф. Р-635, оп. 1, спр. 95, арк. 76-77).

Дещо іншу тенденцію можна простежити в лісових районах Волині. Там поряд із орною землею цінували сіножаті та ліси. Тому в Рафалівському районі Рівненської області на квітень 1941 року за архівними даними щодо 28 сіл було відрізано 1 044,95 га землі, з якої орної було 312,89 га, сіножатей - 350,68 га, пасовищ 95,55 га, інших категорій землі, зокрема й лісів, - 285,83 га. Тут також лише певна частина «відрізків» йшла для наділення землею безземельних і малоземельних селян (ДАРО Ф. Р-635, оп. 1, спр. 109, арк. 2). Більшість землі передали не малоземельним чи безземельним селянам, а новоствореним колгоспам або приєднали до державного земельного фонду (ДАРО Ф. Р-635, оп. 1, спр. 106, арк. 2-3; Ф. Р-635, оп. 1, од. 3б. 95, арк. 2, 8-9).

У Державному архіві Рівненської області зберігся документ, у якому подана інформація про відчуження селянських «надлишків» в усіх 30 районах. Використовуючи статистичні методи зіставлення паралельних даних та аналітичного групування, здійснено аналіз даних, який дає змогу дійти висновку, що здебільшого заплановане відчуження було повністю реалізоване. Більшість землі було передано не селянам, а державному земельному фондові та колгоспам.

Так, у Козинському районі із запланованих до конфіскації 867 га землі було відібрано 855 га, 3 них передали земельному фондові 305 га, колгоспам - 472 га, а малоземельним селянам роздали лише 78 га. У Костопільському районі із запланованих до конфіскації 732 га землі було відібрано 673 га, із них передали земельному фондові 315 га, колгоспам - 240 га, а малоземельним селянам роздали усього 116 га.

У Деражнівському районі із запланованих до конфіскації 2044 га землі було відібрано 2012 га, із них передали земельному фондові 1274 га, колгоспам - 632 га, а малоземельним селянам роздали 106 га. Загальна площа відрізаної землі у Рівненській області в 1941 році склала 24640 га. Із цих площ колгоспам було передано 10351 га, державному земельному фондові - 12697 га, державним організаціям - 195 га, а малоземельним селянам усього 1397 га (ДАРО Ф. Р-635, оп. 3, спр. 103, арк. 1, 4-5).

Розподіл землі малоземельним селянам був досить хаотичним і суб'єктивним. Здебільшого селянам надавали по 1 га землі. Так, у селі Обарява 30 малоземельних селянських господарств, які мали від 2 га 
до 4 га землі, наділили землею. В одному випадку селянинові Леонтію Вищитину, сім'я якого складалася iз шести осіб і який мав 3,72 га землі, додали 0,5 га, а Іванові Гологовському, сім'я якого також складалася із шести осіб і який мав 3,35 га землі, додали 1,25 га (ДАРО Ф. Р-635, оп. 3, спр. 95, арк. 80).

Такий перерозподіл землі призводив до занепаду економічно міцних селянських господарств-середняків, не давав змоги перетворюватися малоземельним на економічно міцні самодостатні середняцькі господарства. Водночас передачею незначної частини націоналізованих земель безземельним і малоземельним селянам радянська влада прагнула досягти певного соціального протистояння між різними групами сільського населення та створити для себе соціальну опору на селі.

Усе це мало далекосяжні психологічні та юридичні наслідки. Адже ставили під сумнів не лише засадничі загальнолюдські моральні принципи, але й багатовікову європейську правову культуру населення у ставленні до приватної власності загалом і земельної зокрема. У спеціальній історичній літературі радянського періоду завуальовано натякали (Варецький, 1960: 118) на численні факти (а в сучасних джерелах їх відкрито наводять), коли місцеві селяни, виховані в традиціях поваги до приватної власності, відмовлялися брати чужу конфісковану землю (Старка, 2015: 119; Кравчук, 2017: 106). Тому до кінця 1939 року селяни не розібрали навіть половини поміщицьких земель. Усі конфісковані ділянки не були розібрані й до червня 1941 року.

Націоналізація та передавання землі у державну власність перетворювали усіх селян із власників на користувачів. Селяни, які важкою працею поколіннями заробляли на придбання власної землі, одномоментно їі втрачали без будь-якої компенсації.

Висновки. У результаті аграрних трансформацій на західноукраїнських землях у 1939-1941 роках комуністична влада підірвала одну з базових правових підвалин традиційного селянського господарювання та побуту - приватну власність на землю. Попри декларації радянської влади малоземельним і безземельним селянам Волині було передано не досить конфіскованої у великих землевласників землі для ведення самоокупного господарства. Середняцькі ж господарства, площа яких перевищувала встановлені радянською владою граничні норми індивідуального землекористування, через відчуження землі перетворили на економічно слабкі.

Заходи радянської влади у сфері правового регулювання земельних відносин переслідували мету не встановити соціальну справедливість і покращити добробут сільського населення, а за допомогою суворої регламентації та посилення державного контролю земельних відносин перетворити більшість індивідуальних селянських господарств на економічно слабкі, які не були б спроможними вистояти перед тягарем прогресуючих державних податків.

Більшість конфіскованої землі перейшла не до селянських господарств, а до радянської держави через іi1 суб'єктів господарювання - новостворені колгоспи та радгоспи, а також у державний земельний фонд. У такий спосіб готували економічне й психологічне підгрунтя до загальної колективізації західноукраїнського села, створення соціалістичного сільського господарства у його більшовицькому варіанті.

\section{Список використаних джерел:}

1. Варецький В.Л. Соичіалістичні перетворення у західних областях УРСР (у довоєнний час). Київ : Видавництво Академії наук УРСР, 1960. 298 с.

2. Вісин В.В. Радянський режим у Волинській області (вересень 1939-червень 1941 рр.). Автореферат дисертації на здобуття наукового ступеня кандидата історичних наук за спеціальністю 07.00.01 - Історія України. Львів, 1997. 21 с.

3. Воссоединение украинского народа в едином Украинском Советском государстве (1939-1949 г2.). Сборник документов и материалов. Киев : Госполитиздат УССР, 1949. 224 с.

4. Державний Архів Ровенської області. Ф. Р-635, оп. 1, спр. 95, 91 арк.

5. Державний Архів Ровенської області. Ф. Р-635, оп. 1, спр. 104, 3 арк.

6. Державний Архів Ровенської області. Ф. Р-635, оп. 1, спр. 106, 3 арк.

7. Державний Архів Ровенської області. Ф. Р-635, оп. 1, спр. 107, 18 арк.

8. Державний Архів Ровенської області. Ф. Р-635, оп. 1, спр. 109, 8 арк.

9. Державний Архів Ровенської області. Ф. Р-635, оп. 1, спр. 115, 7 арк.

10. Державний Архів Ровенської області. Ф. Р-635, оп. 1, од. зб. 95, 18 арк.

11. Державний Архів Ровенської області. Ф. Р-635, оп. 3, од. зб. 28, 3 арк.

12. Державний Архів Ровенської області. Ф. Р-635, оп. 3, спр. 103, 14 арк.

13. Державний Архів Ровенської області. Ф. Р-635, оп. 3, спр. 102, 4 арк.

14. Історія Украӥнської РСР. Українська РСР у період побудови і зміџнення соиіалістичного суспільства (1921-1941): у 8 т. К. : Наук. думка, 1977. Т. 6. 543 с.

15. Коріненко П.С. Трансформації земельних відносин в українському селі (IX-початок XXI ст.). Порівняльний аналіз. Тернопіль, 2015. $496 \mathrm{c.}$

16. Кравчук Л.В. Соціалістична трансформація сільського господарства Тернопільщини (вересень 1939 - червень 1941 рр.). Наукові записки Тернопільського начіонального педагогічного університету імені Володимира Гнатюка. Серія: Історія. Вип. 1. Ч. 1. 2017. С. 102-108.

17. Мартин А.Г., Прядка Т.М. Історичні аспекти формування земельних відносин $і$ землеустрою в Украӥні. Київ : Центр учбової літератури, 2020. 194 с.

18. Романишин Н. Земельна реформа в Другій Речі Посполитій: шляхи реалізації та наслідки. Проблеми гуманітарних наук : збірник наукових пращь ДДПУ імені Івана Франка. Серія: Історія. Вип. 3/45. 2020. С. 87-100. doi: $10.24919 / 2312-2595.3 / 45.203983$. 
19. Старка В.В. Побут сільського населення Західної України в умовах суспільних трансформацій $1939-1941$ рр. Гілея : науковий вісник. Вип. 146. 2019. С. 97-102

20. Старка В. Відображення повсякденного життя західноукраїнського селянства в умовах суспільно-політичних трансформацій 1939-1941рp. у документальній спадщині Греко-католицької церкви. Наукові записки Тернопільського національного педагогічного університету імені Володимира Гнатюка. Серія: Історія. Вип. 1(2). 2015. С. 117-120.

21. Стасюк О. Роль місцевих рад у політичних та економічних трансформаціях західних областей УРСР повоєнного періоду. Український історичний журнал. Число 4. 2020. С. 97-109. doi: https://doi.org/10.15407/uhj2020.04.097.

\section{References:}

1. Derzhavnyi Arkhiv Rovenskoi oblasti, State Archives of Rivne region, f. P-635, op. 1, spr. 95, 91 ark. [in Ukraine].

2. Derzhavnyi Arkhiv Rovenskoi oblasti, State Archives of Rivne region, f. P-635, op. 1, spr. 106, 3 ark. [in Russia].

3. Derzhavnyi Arkhiv Rovenskoi oblasti, State Archives of Rivne region, f. P-635, op. 1, spr. 107, 18 ark. [in Russia].

4. Derzhavnyi Arkhiv Rovenskoi oblasti, State Archives of Rivne region, f. P-635, op. 1, spr. 109, 8 ark. [in Russia].

5. Derzhavnyi Arkhiv Rovenskoi oblasti, State Archives of Rivne region, f. P-635, op. 1, spr. 115, 7 ark. [in Ukraine].

6. Derzhavnyi Arkhiv Rovenskoi oblasti, State Archives of Rivne region, f. P-635, op. 1, od. zb. 95, 18 ark. [in Ukraine].

7. Derzhavnyi Arkhiv Rovenskoi oblasti, State Archives of Rivne region, f. P-635, op. 3, od. zb. 3, 3 ark. [in Russia].

8. Derzhavnyi Arkhiv Rovenskoi oblasti, State Archives of Rivne region, f. P-635, op. 3, spr. 102, 4 ark. [in Ukraine].

9. Derzhavnyi Arkhiv Rovenskoi oblasti, State Archives of Rivne region, f. P-635, op. 3, spr. 103, 14 ark. [in Russia].

10. Derzhavnyi Arkhiv Rovenskoi oblasti, State Archives of Rivne region, f. P-635, op. 3, spr. 104, 3 ark. [in Russia].

11. Kravchuk L.V. (2017) Sotsialistychna transformatsiia silskoho hospodarstva Ternopilshchyny (veresen 1939 - cherven 1941 rr.). [Socialist transformation of agriculture of Ternopil region (September 1939 - June 1941)]. Naukovi zapysky Ternopilskoho natsionalnoho pedahohichnoho universytetu imeni Volodymyra Hnatiuka. Seriia: Istoriia. Vyp. 1. Ch. 1. P. 102-108 [in Ukraine].

12. Korinenko P.S. (2015) Transformatsii zemelnykh vidnosyn v ukrainskomu seli (IX-pochatok XXI st.). Porivnialnyi analiz. [Transformations of land relations in the Ukrainian countryside (IX - beginning of the XXI century). Comparative analysis]. Ternopil. 496 p. [in Ukraine].

13. Istoriia Ukrainskoi RSR. Ukrainska RSR u period pobudovy i zmitsnennia sotsialistychnoho suspilstva (1921-1941) (1977). [History of the Ukrainian SSR. Ukrainian SSR in the period of building and strengthening socialist society (1921-1941)]: u 8 t. Kyiv : Naukova dumka, T. 6. 543 p. [in Ukraine].

14. Martyn A.H., Priadka T.M. (2019). Istorychni aspekty formuvannia zemelnykh vidnosyn i zemleustroiu v Ukraini. [Historical aspects of land relations formation and land management in Ukraine]. Kyiv : Tsentr uchbovoi literatury. 194 p. [in Ukraine].

15. Romanyshyn N. (2020) Zemelna reforma v Druhii Rechi Pospolytii: shliakhy realizatsii ta naslidky [Land reform in the Second Polish Republic: implementation and consequences]. Problemy humanitarnykh nauk : zbirnyk naukovykh prats Drohobytskoho derzhavnoho pedahohichnoho universytetu imeni Ivana Franka. Seriia Istoriia - Problems of Humanities. Drohobych, Vyp. 3/45, P. 87-100. doi: 10.24919/2312-2595.3/45.203983 [in Ukraine].

16. Starka V.V. (2019) Pobut silskoho naselennia Zakhidnoi Ukrainy v umovakh suspilnykh transformatsii $1939-1941$ rr. [The life of the rural population in Western Ukraine in conditions of public act 1939-1941] Hileia : naukovyi visnyk. Kyiv. Vyp. 146. P. 97-102 [in Ukraine].

17. Starka V. (2015) Vidobrazhennia povsiakdennoho zhyttia zakhidnoukrainskoho selianstva v umovakh suspilno-politychnykh transformatsii 1939-1941 rr. v dokumentalnii spadshchyni Hreko-katolytskoi tserkvy. [A reflection of everyday life of westernpeasantry is in the conditions of socialand political transformations 1939-1941 in documentary inheritance of the Greek Catholic church]. Naukovi zapysky Ternopilskoho natsionalnoho pedahohichnoho universytetu imeni Volodymyra Hnatiuka. Seriia : Istoriia. Vyp. 1(2). P. 117-120 [in Ukraine].

18. Stasiuk O. (2020) Rol mistsevykh rad u politychnykh ta ekonomichnykh transformatsiiakh zakhidnykh oblastei URSR povoiennoho periodu. [The Role of Local Councils in the Political and Economic Transformations of the Western Regions of UkrSSR in the Postwar Period]. Ukrainskyi istorychnyi zhurnal. Kyiv, Chyslo 4. P. 97-109. doi: https://doi.org/10.15407/ uhj2020.04.097 [in Ukraine].

19. Varetskyi V.L. (1960) Sotsialistychni peretvorennia u zakhidnykh oblastiakh URSR (v dovoennyi chas) [Socialist transformations in the western regions of the USSR (in the pre-war period)]. Kyiv : Akad. nauk URSR. 298 p. [in Ukraine].

20. Visyn V.V. (1997) Radianskyi rezhym u Volynskii oblasti (veresen 1939 - cherven 1941 rr.). [Soviet regime in the Volyn region (September 1939 - June 1941)]. Avtoreferat dysertatsii na zdobuttia naukovoho stupenia kandydata istorychnykh nauk za spetsialnistiu 07.00.01. Istoriia Ukrainy. Lviv, 1997. 21 s. [in Ukraine].

21. Vossoedinenie ukrainskogo naroda v edinom Ukrainskom Sovetskom gosudarstve (1939-1949 gg.). Sbornik dokumentov $i$ materialov (1949). [Reunification of the Ukrainian people in a single Ukrainian Soviet state (1939-1949). Collection of documents and materials]. Kiev : Gospolitizdat USSR. 224 p. [in Russian]. 